\title{
Potentiation of intestinal immunity by micellary mushroom extracts
}

\author{
Jiwei Shen ${ }^{1,2}$, Hongwei Ren ${ }^{1}$, Chikako Tomiyama-Miyaji ${ }^{3}$, Yasuyo Suga ${ }^{4}$, Tetsuya Suga ${ }^{4}$, Yuh Kuwano \\ Tsuneo IiAi ${ }^{2}$, Katsuyoshi HataKeYAMA ${ }^{2}$ and Toru ABo ${ }^{1}$ \\ ${ }^{1}$ Department of Immunology; ${ }^{2}$ First Department of Surgery, Niigata University School of Medicine; ${ }^{3}$ School of Health Sciences, Faculty \\ of Medicine, Niigata University, Niigata; and ${ }^{4}$ Pharmaceutical Research Laboratories, Ajinomoto Co. Inc., Kawasaki, Japan
}

(Received 28 December 2006; and accepted 18 January 2007)

\begin{abstract}
Mushroom (shiitake) extracts were dispersed with lecithin micelles to prepare superfine particles ( 0.05 to $0.2 \mu \mathrm{m}$ in diameter) of $\beta$-1,3-glucan (micellary mushroom extracts). When mice were fed with these micelles of $\beta$-glucan $(0.75 \mathrm{mg} /$ day/mouse, smaller amounts of $\beta$-glucan $)$, the number of lymphocytes yielded by the small intestine increased by up to $40 \%$. More interestingly, the ratio of $\mathrm{CD} 8 \alpha \beta^{+} \mathrm{TCR} \alpha \beta^{+}$cells/CD $8 \alpha \alpha^{+} \mathrm{TCR} \alpha \beta^{+}$cells increased prominently. In parallel with this deviation in the distribution of lymphocyte subsets, tumor cytotoxicity against P815 cells and cytokine productions were also augmented. In other words, phylogenetically developed lymphocytes $\left(\mathrm{CD} 8 \alpha \beta^{+}, \mathrm{TCR} \alpha \beta^{+}\right)$were much more effectively activated by the oral administration of micellary $\beta$-glucan. These results suggest that smaller amounts of micellary $\beta$-glucan might be useful for the potentiation of intestinal immunity.
\end{abstract}

It is empirically known that mushrooms, especially components of $\beta$-glucan, are good for our health $(2,6$, $10,14,17,21)$ and sometimes show anti-tumor effects in animal models and humans $(3,4,15)$. However, such anti-tumor effects of crude mushroom extracts were limited in our preliminary experiments. To overcome this, we prepared superfine particles of $\beta$-1,3-glucan (i.e., mushroom extracts) dispersed with lecithin micelles using a high-pressure emulsifier in this study. These mushroom (shiitake) extracts were then used to examine whether oral administration has the potential to induce the augmentation of intestinal immunity in mice. Cumulative evidence has revealed that the augmentation of intestinal immunity is extremely important for immunological tolerance, anti-tumor effects, innate immunity against intracellular pathogens, etc. $(1,7,8$, $13,18)$. The present results indicate that micellary

Address correspondence to: Dr T. Abo, Department of Immunology, Niigata University School of Medicine, Niigata 951-8510, Japan

Fax: +81-25-227-0766

E-mail: immunol2@med.niigata-u.ac.jp mushroom extracts might have such potential via the augmentation of intestinal immunity, especially in the small intestine.

\section{MATERIALS AND METHODS}

Mice. C57BL/6 (B6) mice at the age of 8-10 weeks were used in this study. The mice were maintained in the animal facility of Niigata University (Niigata, Japan). All mice were fed under specific pathogenfree conditions. All experimental procedures were approved by the Committee on Animal Research of Niigata University.

Oral administration of shiitake extracts. Shiitake mushrooms were broken down with a colloid mill and boiled at $95^{\circ} \mathrm{C}$ for $3 \mathrm{~h}$ in hot water, and the resulting extracts were filtered. These extracts were then mixed with lecithin and dispersed at $1500 \mathrm{kgf} /$ $\mathrm{cm}^{2}$ with a high-pressure emulsifier (Ajinomoto Co. Inc., Kawasaki, Japan). Particles of $\beta$-1,3-glucan in the shiitake extracts $(10 \sim 1000 \mu \mathrm{m})$ became smaller up to particle size of 0.05 to $0.2 \mu \mathrm{m}$ (Fig. 1). The major component of the superfine particles was 
A

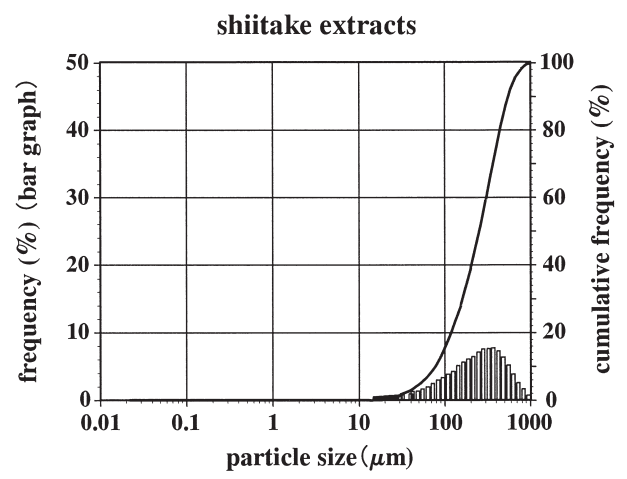

$\mathbf{B}$

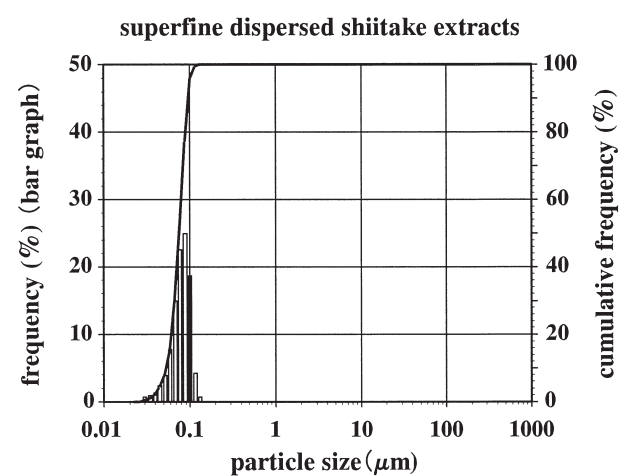

Fig. 1 Particle size distribution of the shiitake extract. A. Crude shiitake extracts, B. Micellary shiitake extracts. Shiitake extracts were mixed with lecithin and were dispersed at $1500 \mathrm{kgf} / \mathrm{cm}^{2}$ using a high-pressure emulsifier. Diameter of particles was determined by a laser diffraction/scattering particle size distribution meter.

$\beta$-glucan. The concentration of $\beta$-glucan was quantitatively determined using Congo red solution by measuring the absorbance at $535 \mathrm{~nm}$ with a spectrophotometer. These micellary extracts were diluted with drinking water, which mice drank from a bottle for 2 weeks ( $0.75 \mathrm{mg} /$ day/mouse) .

Cell preparation. Mice anesthetized with ether were sacrificed by total bleeding from the incised axillary artery and vein. The organs to be used for the experiments were removed and lymphocytes were obtained as follows. Hepatic lymphocytes were isolated by a previously described method (22). Briefly, the liver was pressed through 200-gauge stainless steel mesh and suspended in Eagle's MEM medium (Nissui Pharmaceutical, Tokyo, Japan) supplemented with $5 \mathrm{mM}$ Hepes and $2 \%$ heat-inactivated newborn calf serum. After being washed once with the medium, the cells were fractionated by centrifugation in $15 \mathrm{~mL}$ of $35 \%$ Percoll solution (Amersham Biosci- ences, Uppsala, Sweden) for $15 \mathrm{~min}$ at $440 \times \mathrm{g}$. The resulting pellet was resuspended in erythrocyte lysing solution $\left(155 \mathrm{mM} \mathrm{NH}_{4} \mathrm{Cl}, 10 \mathrm{mM} \mathrm{KHCO}_{3}\right.$, $1 \mathrm{mM}$ EDTA-Na, and $17 \mathrm{mM}$ Tris, pH 7.3). Splenocytes were obtained by forcing the spleen through 200 -gauge stainless steel mesh. Splenocytes were treated with $0.2 \% \mathrm{NaCl}$ solution to remove RBC.

Intraepithelial lymphocytes (IEL) were collected from the small intestine according to a previously described method (19). Briefly, the small intestine was removed and flushed with PBS to eliminate luminal contents. The mesentery and Peyer's patches were then resected. The intestine was opened longitudinally and cut into $1-2 \mathrm{~cm}$ fragments. These fragments were incubated for $15 \mathrm{~min}$ in $20 \mathrm{~mL} \mathrm{Ca}{ }^{2+}$ and $\mathrm{Mg}^{2+}$-free Dulbecco's PBS containing $5 \mathrm{mM}$ EDTA, in a $37^{\circ} \mathrm{C}$ shaking-water bath. The supernatant was then collected. The cell suspensions were collected and centrifuged in a discontinuous $40 \% / 80 \%$ Percoll gradient at $830 \times g$ for $25 \mathrm{~min}$. Cells from the $40 \% / 80 \%$ interface were collected.

Immunofluorescence tests. Standard flow cytometric analysis was performed as previously described (16). FITC-conjugated anti-CD3 (145-2C11), anti-CD8 $\alpha$ (53-6.7), PE-conjugated anti-NK1.1 (PK136), antiIL-2R $\beta$ (TM- $\beta 1$ ), anti-CD45R/B220 (RA3-6B2), anti-CD4 (PM4-5), anti-CD8 $\beta$ (53-5.8), biotinconjugated anti-TCR $\alpha \beta$ (H57-597), anti-TCR $\gamma \delta$ mAbs (GL3) and their isotype controls were purchased from BD PharMingen (San Diego, CA). Biotin-conjugated reagents were developed with Tricolor conjugated streptavidin (Caltag Lab, San Francisco, CA).

Cytotoxicity assay. Cytotoxicity assay was performed as previously described (5). YAC-1 and P815 target cells were labeled with sodium $\left[{ }^{51} \mathrm{Cr}\right]$ chromate (NEN Life Science Products, Boston, MA) for $2 \mathrm{~h}$ and washed three times with RPMI- 1640 medium supplemented with $10 \%$ fetal calf serum (FCS). P815 target cells were preincubated with anti-TCR $\alpha \beta$ (H57-597, $1 \mu \mathrm{g} / \mathrm{mL})$, anti-TCR $\gamma \delta$ (GL3, $1 \mu \mathrm{g} / \mathrm{mL})$, and anti-CD3e $(145-2 \mathrm{C} 11,1 \mu \mathrm{g} / \mathrm{mL})$, respectively. Effector cells were serially diluted and mixed with $\left[{ }^{51} \mathrm{Cr}\right]$-labeled target cells $\left(1 \times 10^{4}\right.$ cells $)$ in a 96-well U-bottomed microculture plate. The plate was centrifuged and incubated for $4 \mathrm{~h}$ at $37^{\circ} \mathrm{C}$. At the end of the culture, $100 \mathrm{~mL}$ of supernatant was counted in a gamma counter.

Quantification of cytokines. Sera obtained from each mouse were used to detect the concentration of in- 
terleukin-2 (IL-2) and tumor necrosis factor $\alpha(\mathrm{TNF} \alpha)$ using Cytometric Bead Array (CBA) kits (BD Biosciences, San Jose, CA) according to the manufacturer's instructions. The CBA technique is based on microparticles matched with antibodies, in which the particles are dyed to different fluorescence intensities. Following acquisition of sample data using a FACScan (BD Biosciences), the sample results were generated in graphical and tabular formats using $\mathrm{BD}$ CBA Analysis Software (BD Biosciences).

Statistical analysis. The difference between the values was determined by Student's $t$-test.

\section{RESULTS}

Immunopotentiation in the small intestine by the administration of $\beta$-glucan

Mice drank pure water or water with shiitake extracts (i.e., micellary $\beta$-glucan) for 2 weeks and the numbers of lymphocytes yielded by the liver, spleen and small intestine were enumerated (Fig. 2). The numbers of lymphocytes in the liver and spleen were unchanged by the oral administration of $\beta$-glucan, whereas that in the small intestine (intraepithelial lymphocytes, IEL) increased up to $40 \%$ by the administration of $\beta$-glucan ( $\mathrm{n}=4, \mathrm{p}<0.05$ ).

To determine the distribution of lymphocyte subsets in various immune organs, two-color staining for CD3 and IL-2R $\beta$ and that for CD3 and NK1.1 were then conducted (Fig. 3A). Mice fed with or without $\beta$-glucan were examined on day 14 . In the liver, CD ${ }^{-} \mathrm{IL}^{-2 \mathrm{R}} \beta^{+}$were NK cells, CD ${ }^{\text {int }} \mathrm{IL}-2 \mathrm{R} \beta^{+}$ were extrathymic $\mathrm{T}$ cells and $\mathrm{CD} 3^{\text {high }} \mathrm{IL}-2 \mathrm{R} \beta^{-}$were conventional $\mathrm{T}$ cells of thymic origin (20). NK cells and extrathymic $\mathrm{T}$ cells were abundant in the liver, but these subsets were few in the spleen. The distribution patterns of these lymphocyte subsets were unchanged in the liver and spleen, irrespective of the administration of $\beta$-glucan. In the case of the small intestine, $\mathrm{CD}^{+} \mathrm{IL}-2 \mathrm{R} \beta^{-}$(mainly $\alpha \beta \mathrm{T}$ cells) and $\mathrm{CD}^{+} \mathrm{IL}-2 \mathrm{R} \beta^{+}$(mainly $\gamma \delta \mathrm{T}$ cells) were present. This pattern was also unchanged by the administration of $\beta$-glucan. A similar staining pattern was also produced by two-color staining for CD3 and NK1.1 (Fig. 3A bottom). The patterns were also confirmed to be unchanged by $\beta$-glucan in this staining. $\mathrm{CD}^{-}$ NK $1.1^{+}$were NK cells and CD $3{ }^{\text {int }} \mathrm{NK} 1.1^{+}$were NKT cells (approximately $50 \%$ of extrathymic $\mathrm{T}$ cells were NKT cells).

To further characterize the phenotype of lymphocyte subsets, stainings with various combinations were conducted, especially in the small intestine
(Fig. 3B). Among IEL in the small intestine (s-IEL), B220 ${ }^{+} \mathrm{T}$ cells were present. Their level became low by the administration of $\beta$-glucan $(35.1 \% \rightarrow 24.9 \%)$. Two-color staining for CD4 and CD8 showed that the proportion of $\mathrm{CD} 8^{+}$cells became high by $\beta$-glucan. This population was found to contain high proportions of TCR $\alpha \beta^{+}$cells and $\mathrm{CD} 8 \alpha^{+} \mathrm{CD} 8 \beta^{-}$cells (i.e., CD8 $\alpha \alpha$ homodimer cells).

We then examined the distribution of TCR $\alpha \beta^{+}$and TCR $\gamma \delta^{+}$cells among $\mathrm{CD} 8 \alpha^{+} \beta^{+}$cells and $\mathrm{CD} 8 \alpha^{+} \beta^{-}$ cells in the small intestine (Fig. 4). Three-color staining for $\mathrm{CD} 8 \alpha, \mathrm{CD} 8 \beta$ and $\mathrm{TCR} \alpha \beta$ (or $\mathrm{TCR} \gamma \delta$ ) was conducted. By gated analysis, the proportion of $\mathrm{TCR} \alpha \beta^{+}$cells and $\mathrm{TCR} \gamma \delta^{+}$cells was estimated. In normal mice, approximately $60 \%$ of the $\mathrm{CD} 8 \alpha \beta$ cells were TCR $\alpha \beta^{+}$and $40 \%$ of them were $\mathrm{TCR} \gamma \delta^{+}$. On the other hand, approximately $30 \%$ of the CD8 $\alpha \alpha$ cells were TCR $\alpha \beta^{+}$and $70 \%$ of them were $\mathrm{TCR} \gamma \delta^{+}$. The administration of $\beta$-glucan changed this distribution pattern, namely, the proportion of $\mathrm{TCR} \alpha \beta^{+}$cells increased and that of TCR $\gamma \delta^{+}$cells decreased among both CD8 $\alpha \beta$ cells and CD8 $\alpha \alpha$ cells.

All these experiments were repeated $(n=4)$ and the absolute numbers of various lymphocyte subsets were calculated (Fig. 5). The number of whole $\mathrm{CD} 8^{+}$ cells increased prominently by the administration of $\beta$-glucan $(\mathrm{p}<0.05)$. Among $\mathrm{CD} 8^{+}$cells, the increase in the number of CD8 $\alpha \alpha$ cells was much more prominent than that of $\mathrm{CD} 8 \alpha \beta$ cells. The number of TCR $\alpha \beta^{+}$cells increased $(\mathrm{p}<0.05)$, but that of $\mathrm{TCR} \gamma \delta^{+}$cells increased only slightly.

\section{Total lymphocytes}

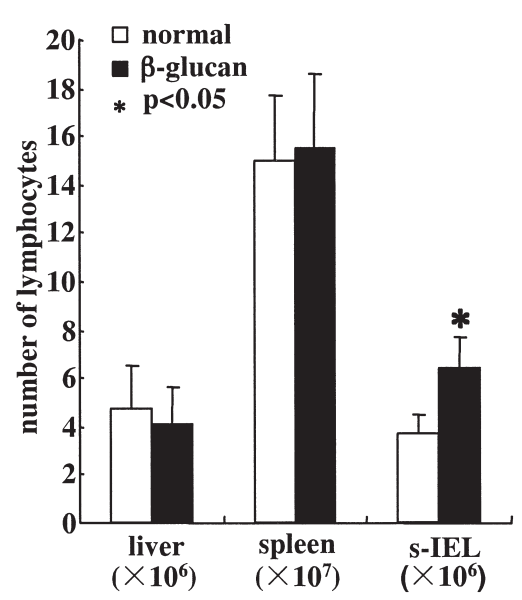

Fig. 2 Number of total lymphocytes yielded by the liver, spleen and small intestine in mice fed with or without $\beta$-glucan. Four mice were used to produce the mean and one SD. 
A

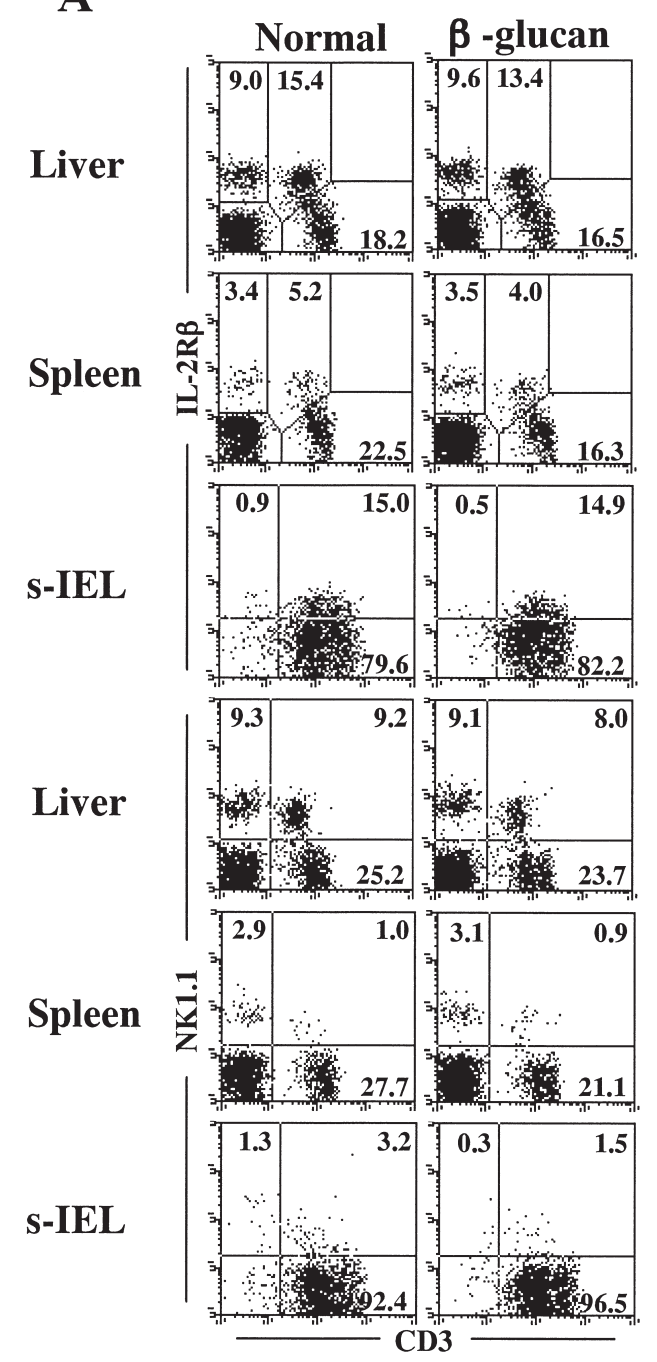

B
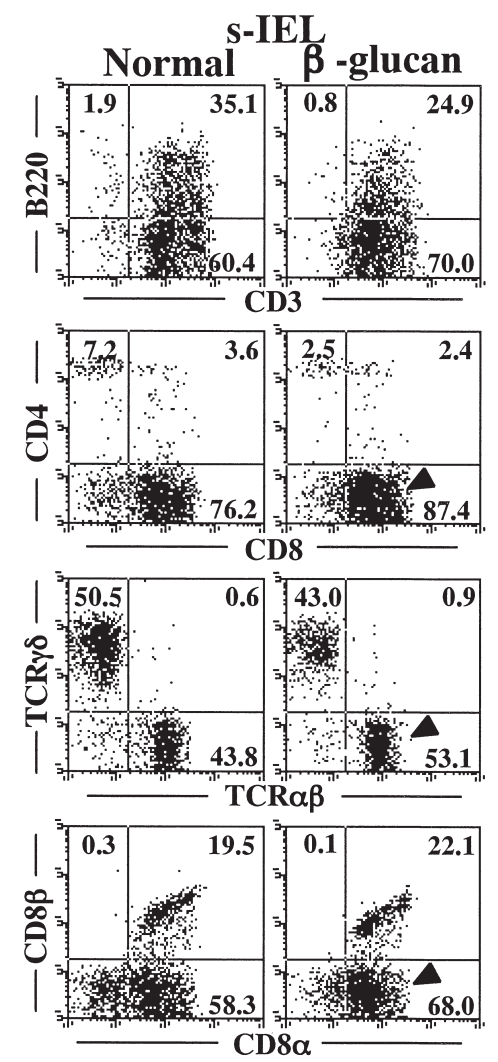

Fig. 3 Phenotypic characterization of lymphocytes by two-color immunofluorescence tests. A. Two-color staining for CD3 and IL-2R $\beta$ (or NK1.1), B. Two-color staining for various combinations. Numbers in the figure represent the percentages of fluorescence-positive cells in corresponding areas. Representative results of three experiments are depicted.

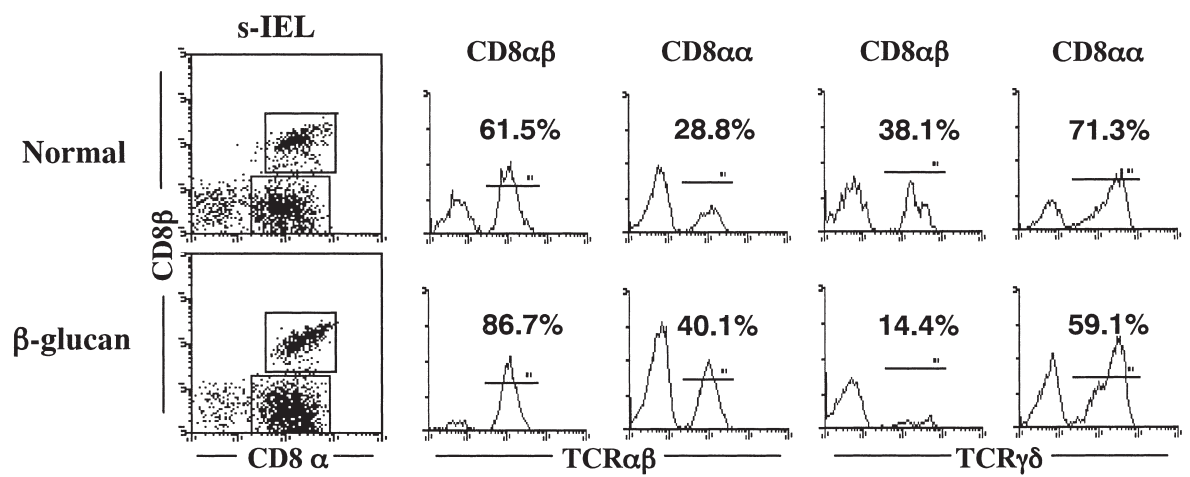

Fig. 4 Phenotypic characterization of lymphocyte subsets in the small intestine. IEL were isolated from the small intestine in mice fed with or without $\beta$-glucan. Three-color staining for CD8 $a, \operatorname{CD} 8 \beta$ and TCR $\alpha \beta$ (or TCR $\gamma \delta$ ) was conducted. By gated analysis, the expression of TCR $\alpha \beta$ and TCR $\gamma \delta$ was estimated in CD8a $\beta$ cells and CD8aa cells. Numbers in the figure represent the percentage of fluorescence-positive cells in corresponding areas. 


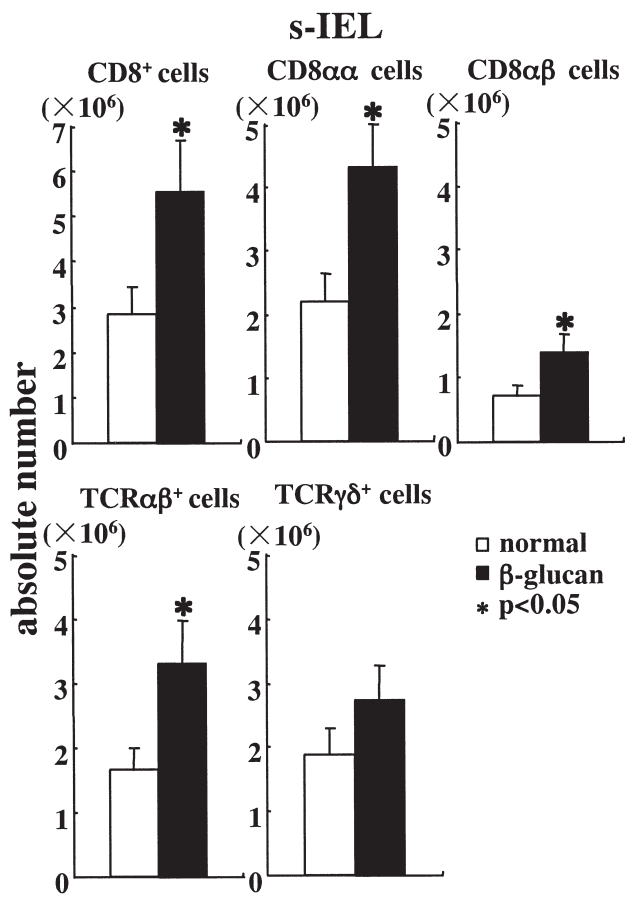

Fig. 5 Comparisons of the absolute number of lymphocyte subsets in the small intestine between mice fed without $\beta$-glucan and with $\beta$-glucan. Four mice were used to produce the mean and one SD.

Augmented cytotoxicity of IEL in the small intestine by $\beta$-glucan

Cytotoxicity assays against YAC-1 cells (i.e., NK cytotoxicity) and against P815 cells (i.e., tumor cytotoxicity) were conducted (Fig. 6). Primarily, lymphocytes isolated from the liver had high NK cytotoxicity but those isolated from the spleen and small intestine had low NK cytotoxicity (9). This tendency was confirmed in mice fed with or without $\beta$-glucan (Fig. 6A). In other words, the administration of $\beta$-glucan did not have a significant effect on NK cytotoxicity.

It is known that IEL in the small intestine carry tumor cytotoxicity against P815 myeloma cells and this cytotoxicity is augmented by anti-CD3, anti$\mathrm{TCR} \alpha \beta$ and anti-TCR $\gamma \delta \mathrm{mAbs}$ coated on assay plates (5). These experiments were conducted in IEL in the small intestine of mice fed with or without $\beta$-glucan (Fig. 6B). Under all tested conditions except of anti-CD3 mAb, IEL isolated from mice fed with $\beta$-glucan showed augmented levels of tumor cytotoxicity $(\mathrm{p}<0.05)$.

Cytokine levels increased in sera by administration of $\beta$-glucan

As is well-known, pro-inflammatory cytokines such
A

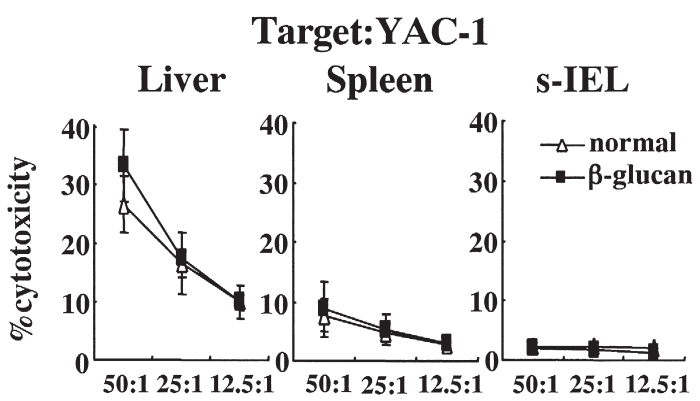

B

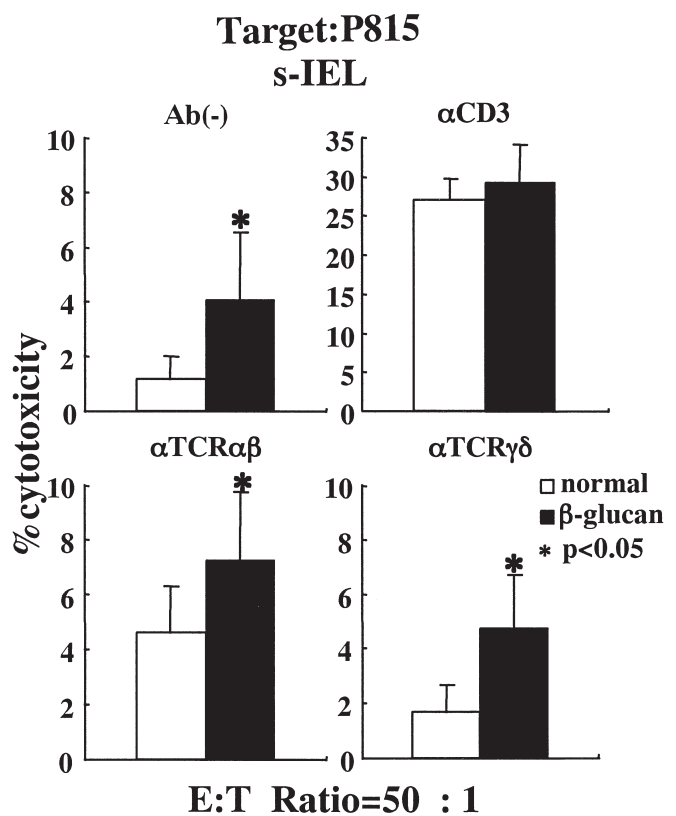

Fig. 6 Cytotoxic activity of lymphocytes. A. NK cytotoxicity against YAC-1 cells, B. Tumor cytotoxicity against P815 cells. Lymphocytes were isolated from the liver, spleen and small intestine in mice fed with or without $\beta$-glucan. Cytotoxicity was examined at the indicated effector to target (E:T) ratios. By three independent experiments, the mean and one SD were produced.

as TNF- $\alpha$ are important for host defense. Furthermore, several investigators have reported that the production of cytokines (e.g. TNF $\alpha$ and IL-1) in mice was enhanced by administration of $\beta$-glucan (11, 12). To determine if cytokine levels increased by the administration of $\beta$-glucan, in a final portion of these experiments, the levels of TNF $\alpha$ and IL-2 were examined in sera of mice fed with or without $\beta$-glucan (Fig. 7). In the sera of mice that underwent the administration of $\beta$-glucan, CBA assay detected prominently increased levels of TNF $\alpha(3.2 \mathrm{pg} / \mathrm{mL} \rightarrow$ $5.4 \mathrm{pg} / \mathrm{mL})$ and IL-2 $(1.6 \mathrm{pg} / \mathrm{mL} \rightarrow 3.6 \mathrm{pg} / \mathrm{mL})$, 


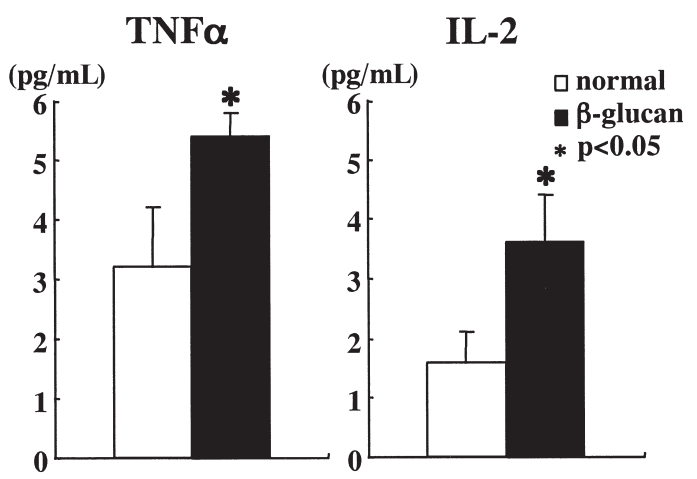

Fig. 7 Cytokine production from sera. Lymphocytes were isolated from mice fed with or without $\beta$-glucan. By three experiments, the mean and one SD were produced.

compared to levels in the mice without $\beta$-glucan $(\mathrm{n}=3, \mathrm{p}<0.05)$. The levels of IFN- $\gamma$, IL-4 and IL-5 were also examined, but were unchanged by the oral administration of $\beta$-glucan (data not shown).

\section{DISCUSSION}

In the present study, we demonstrated that micellary $\beta$-1,3-glucan prepared from shiitake extracts was able to potentiate intestinal immunity. The number of lymphocytes yielded by the small intestine increased and the tumor cytotoxicity against P815 cells was augmented by the oral administration of micellary $\beta$-glucan. Although there have been some reports that crude-sized $\beta$-glucan potentiates intestinal immunity (19), we herein used superfine particles of $\beta$-glucan dispersed with lecithin micelles. The smaller amounts of micellary $\beta$-glucan seemed to be more effective for the potentiation of immunity than crude-sized $\beta$-glucan. The earlier reports showed that crude-sized $\beta$-glucan was required at the level of $10-30 \mathrm{mg} /$ day/mouse for immunopotentiation (19). However, less than $1 \mathrm{mg} /$ day/mouse of micellary $\beta$-glucan was effective for the same level of potentiation.

Primarily, $\beta$ - 1,3 -glucan is the major component of oats, mushrooms and yeasts $(2,6,10,14,17,21)$. Since $\beta$-1,3-glucan is an indigestive sugar for humans, almost all of the large fragments of this sugar might be unabsorbed from the small intestine. It is speculated that this situation explains the limited function of crude-sized $\beta$-1,3-glucan for the immunopotentiation of intestinal immunity $(3,4,15)$. To overcome this situation, we prepared micellary mushroom extracts containing superfine particles of $\beta$-1,3-glucan, using lecithin micelles and a highpressure emulsifier. The crude-sized $\beta$-glucan ranged from 10 to $1000 \mu \mathrm{m}$ of diameter, whereas micellary $\beta$-glucan ranged from 0.05 to $0.2 \mu \mathrm{m}$ in diameter. In other words, findings of the present study suggest that a small amount of micellary $\beta$-glucan is sufficient to potentiate intestinal immunity. Some patients such as those with digestive tract malignancy might have difficulty in taking a large amount of $\beta$-glucan. In that case, micellary $\beta$-glucan might be very useful.

Similar to other data on crude-sized $\beta$-glucan (19), an increase in the number of lymphocytes in the small intestine was prominent even by the oral administration of micellary $\beta$-glucan. However, relative enrichment of $\mathrm{CD} 8 \alpha \beta^{+} \mathrm{TCR} \alpha \beta^{+}$cells was unique. On the other hand, the proportion of CD8 $\alpha \alpha^{+} \mathrm{TCR} \gamma \delta^{+}$ cells slightly declined (see Fig. 4). These results suggest that phylogenetically developed $\mathrm{T}$ cells in the intestine are efficiently activated by micellary $\beta$-glucan. These results are also related to the augmentation of tumor cytotoxicity and the increased production of TNF- $\alpha$ and IL-2. Our preliminary experiments revealed that $\mathrm{CD} 8 \alpha \beta^{+} \mathrm{TCR} \alpha \beta^{+}$cells had a higher ability of the above-mentioned functions (data not shown). In sharp contrast, CD $8 \alpha \alpha^{+}$(CD8 homodimer) cells and TCR $\gamma \delta^{+}$cells are known to be the most primitive form of lymphocyte subsets in phylogeny. In any case, micellary $\beta$-glucan may be expected to be effective for the potentiation of intestinal immunity in other animals and humans.

\section{Acknowledgements}

This work was supported by a Grant-in-Aid for Scientific Research from the Ministry of Education, Science, and Culture, Japan. The authors thank Mrs Yuko Kaneko for preparation of the manuscript.

\section{REFERENCES}

1. Bakir HY, Tomiyama-Miyaji C, Watanabe H, Nagura T, Kawamura T, Sekikawa H and Abo T (2006) Reasons why DBA/2 mice are resistant to malarial infection: expansion of $\mathrm{CD} 3^{\text {int }} \mathrm{B} 220^{+} \gamma \delta \mathrm{T}$ cells with double-negative $\mathrm{CD} 4^{-} 8^{-}$phenotype in the liver. Immunology 17, 127-135.

2. Battilana P, Ornstein K, Minehira K, Schwarz JM, Acheson K, Schneiter P, Burri J, Jequier E and Tappy L (2001) Mechanisms of action of $\beta$-glucan in postprandial glucose metabolism in healthy men. Eur J Clin Nutr 55, 327-333.

3. Chihara G, Hamuro J, Maeda Y, Arai Y and Fukuda F (1970) Fractionation and purification of the polysaccharides with marked antitumor activity, especially lentinan, from Lentinus edodes (Berk.) sing. (an edible mushroom). Cancer Res 30, 2776-2781.

4. Chihara G, Maeda Y, Hamuro J, Sasaki T and Fukuoka F (1969) Inhibition of mouse sarcoma 180 by polysaccharides from Lentinus edodes (Berk.) sing. Nature 222, 687-688. 
5. Emoto M, Neuhaus O, Emoto Y and Kaufmann SH (1996) Influence of $\beta_{2}$-microglobulin expression on gamma interferon secretion and target cell lysis by intraepithelial lymphocytes during intestinal Listeria monocytogenes infection. Infect Immun 64, 569-575.

6. Englyst HN and Cummings JH (1985) Digestion of the polysaccharides of some cereal foods in the human small intestine. Am J Clin Nutr 42, 778-787.

7. Ishimoto $\mathrm{Y}$, Tomiyama-Miyaji C, Watanabe H, Yokoyama H, Ebe K, Tsubata S, Aoyagi Y and Abo T (2004) Age-dependent variation in the proportion and number of intestinal lymphocyte subsets, especially natural killer $\mathrm{T}$ cells, doublepositive $\mathrm{CD}^{+} \mathrm{CD} 8^{+}$cells and $\mathrm{B} 220^{+} \mathrm{T}$ cells, in mice. Immunology 113, 371-377.

8. Kawamura H, Kameyama H, Kosaka T, Kuwahara O, Bannai M, Kawamura T, Watanabe $\mathrm{H}$ and Abo T (2002) Association of $\mathrm{CD}^{+}$natural killer $\mathrm{T}$ cells in the liver with neonatal tolerance phenomenon. Transplantation 73, 978-994.

9. Kawamura T, Kawachi Y, Moroda T, Weerashinghe A, Iiai T, Seki S, Tazawa Y, Takada G and Abo T (1996) Cytotoxic activity against tumor cells mediated by intermediate TCR cells in the liver and spleen. Immunology 89, 68-75.

10. Knudsen KE, Jensen BB and Hansen I (1993) Digestion of polysaccharides and other major components in the small and large intestine of pigs fed on diets consisting of oat fractions rich in $\beta$-D-glucan. Br J Nutr 70, 537-556.

11. Kupfahl C, Geginat $G$ and Hod H (2006) Lentinan has a stimulatory effect on innate and adaptive immunity against murine Listeria monocytogenes infection. Int Immunopharmacol 6, 686-696.

12. Lehne G, Haneberg B, Gaustad P, Johansen PW, Preus H and Abrahamsen TG (2006) Oral administration of a new soluble branched $\beta-1,3-\mathrm{D}$-glucan is well tolerated and can lead to increased salivary concentrations of immunoglobulin A in healthy volunteers. Clin Exp Immunol 143, 65-69.

13. Li C, Bai X, Wang S, Tomiyama-Miyaji C, Nagura T, Kawamura $T$ and Abo T (2004) Immunopotentiation of NKT cells by low-protein diet and the suppressive effect on tumor metastasis. Cell Immunol 231, 96-102.

14. Lund EK, Gee JM, Brown JC, Wood PJ and Johnson IT (1989) Effect of oat gum on the physical properties of the gastrointestinal contents and on the uptake of D-galactose and cholesterol by rat small intestine in vitro. Br J Nutr 62, 91-101.

15. Maeda YY and Chihara G (1973) The effects of neonatal thymectomy on the antitumor activity of lentinan, carboxymethylpachymaran and zymosan, and their effects on various immune responses. Int J Cancer 11, 153-161.

16. Miyaji C, Watanabe H, Miyakawa R, Yokoyama H, Tsukada C, Ishimoto $\mathrm{Y}$ and Abo T (2002) Identification of effector cells for TNF $\alpha$-mediated cytotoxicity against WEHI164S cells. Cell Immunol 216, 43-49.

17. Sundberg B, Wood P, Lia A, Andersson H, Sandberg AS, Hallmans G and Aman P (1996) Mixed-linked $\beta$-glucan from breads of different cereals is partly degraded in the human ileostomy model. Am J Clin Nutr 64, 878-885.

18. Takahashi S, Kawamura T, Kanda Y, Taniguchi T, Nishizawa $\mathrm{T}$, Iiai $\mathrm{T}$, Hatakeyama $\mathrm{K}$ and Abo $\mathrm{T}$ (2006) Activation of CD1d-independent NK1.1 $1^{+} \mathrm{T}$ cells in the large intestine by Latobacilli. Immunol Lett 102, 74-78.

19. Tsukada C, Yokoyama H, Miyaji C, Ishimoto Y, Kawamura $\mathrm{H}$ and Abo T (2003) Immunopotentiation of intraepithelial lymphocytes in the intestine by oral administrations of $\beta$-glucan. Cell Immunol 221, 1-5.

20. Watanabe T, Kawamura T, Kawamura H, Haga M, Shirai K, Watanabe H, Eguchi S and Abo T (1997) Intermediate TCR cells in mouse lung. Their effector function to induce pneumonitis in mice with autoimmune-like graft-versus-host disease. J Immunol 158, 5805-5814.

21. Wursch P and Pi-Sunyer FX (1997) The role of viscous soluble fiber in the metabolic control of diabetes. A review with special emphasis on cereals rich in $\beta$-glucan. Diabetes Care 20, 1774-1780.

22. Yamagiwa S, Sugahara S, Shimizu T, Iwanaga T, Yoshida Y, Honda S, Watanabe H, Suzuki K, Asakura H and Abo T (1998) The primary site of $\mathrm{CD}^{-}{ }^{-} \mathrm{B} 220^{+} \alpha \beta \mathrm{T}$ cells in $l p r$ mice: the appendix in normal mice. $J$ Immunol 160, 2665-2674. 
